\title{
First records of dwarf sperm whale (Kogia sima) from the Union of the Comoros
}

\author{
Marco Bonato ${ }^{1,2^{*}}$, Marc A. Webber $^{3}$, Artadji Attoumane ${ }^{4}$ and Cristina Giacoma ${ }^{1}$
}

\begin{abstract}
The world distribution of dwarf and pygmy sperm whales (Cetacea: Kogiidae) [Kogia spp.] is poorly known, and derived mostly from records of stranded animals. At sea, both species are elusive and difficult to identify. We photo-documented the presence of dwarf sperm whale (Kogia sima) in the waters of the Union of the Comoros. All three occurrences were sightings of apparently healthy animals from 2011 to 2013 in and near Itsandra Bay, off the island of Grande Comore. We discuss the importance of the Mozambique Channel and the Agulhas Current Large Marine Ecosystem for the species in the Western Indian Ocean.
\end{abstract}

Keywords: Dwarf sperm whale, Kogia sima, Union of the Comoros, Mozambique channel, Indian ocean

\section{Introduction}

Dwarf sperm whales (Kogia sima) inhabit the warm temperate and tropical waters of the Atlantic, Pacific and Indian Oceans (Rice 1998), primarily from $24^{\circ} \mathrm{N}$ to $40^{\circ} \mathrm{S}$ (Wade \& Gerrodette 1993), although some records are from beyond these limits and as far north as the Faroe Islands (Bloch \& Mikkelsen 2009) and along the west coast of Canada (Nagorsen \& Stewart 1983). Within their range, they occur seaward from the continental slope to deep open ocean waters (Willis \& Baird 1998; Baird 2005). There is some diet-based evidence that they use waters over the continental shelf, and that juveniles occupy shallower waters inshore of adults (Ross 1979b; Plön 2004). Unfortunately, our understanding of the distribution of this species is derived mainly from stranding events (Cardona-Maldonado \& MignucciGiannoni 1999), because sightings at sea are rare, due to their pelagic distribution, small size (adults reach up to $2.7 \mathrm{~m}$ in length), elusive habits, and the need for calm surface conditions for detection (Willis \& Baird 1998; Baird 2005). Dwarf sperm whales take long and presumably deep dives, and when at the surface often remain motionless, keeping a low profile, rarely engaging in active behaviors (Baird 2005). Moreover, this species'

\footnotetext{
* Correspondence: marco.bonato@unito.it

'Department of Life Science and System Biology, University of Torino, Via

Accademia Albertina 13, Torino 10123, Italy

${ }^{2}$ Department of Industrial Engineering (L.A.S.A.), University of Padova, Via

Marzolo 9, Padova 35131, Italy

Full list of author information is available at the end of the article
}

morphological similarity to its congener, the pygmy sperm whale ( $K$. breviceps), makes at sea identification difficult (Willis \& Baird 1998; Baird 2005). From the Indian Ocean area, reports of sightings of dwarf sperm whales have been made from the waters north of the Seychelles to Oman and Sri Lanka, (Balance \& Pitman 1998), Thailand, Indonesia and Western Australia (Willis \& Baird 1998). Only a few sightings have come from the Western Indian Ocean: two off Mayotte Island (Kiszka et al. 2007; Kiszka et al. 2010), and records from Madagascar and the Seychelles are cited by Kiszka et al. (2008). Here, we provide the first evidence of the occurrence of dwarf sperm whales in the waters of the Union of the Comoros and discuss the relevance of the Mozambique Channel as an important area for the species.

\section{Material and methods}

Between April 2011 and September 2013, small ( $<7$ m) motorboat-based surveys were undertaken off the western coast of Grande Comore Island (Ngazidja). During this time period, $4234 \mathrm{~km}$ were surveyed on 135 trips spanning $337 \mathrm{~h}$ of effort (Fig. 1).

The average speed during the surveys was approximately $13 \mathrm{~km} / \mathrm{h}(7 \mathrm{kn})$, at 3-9 km from shore. Observers on board were equipped with $7 \times 50$ binoculars, a digital camera with image-stabilizing zoom lenses (50$200 \mathrm{~mm} / 50-300 \mathrm{~mm})$. Transects and sightings were recorded with a digital GPS unit (Garmin 62-S with an accuracy of $+/-5 \mathrm{~m}$ ) and plotted on a NOAA 


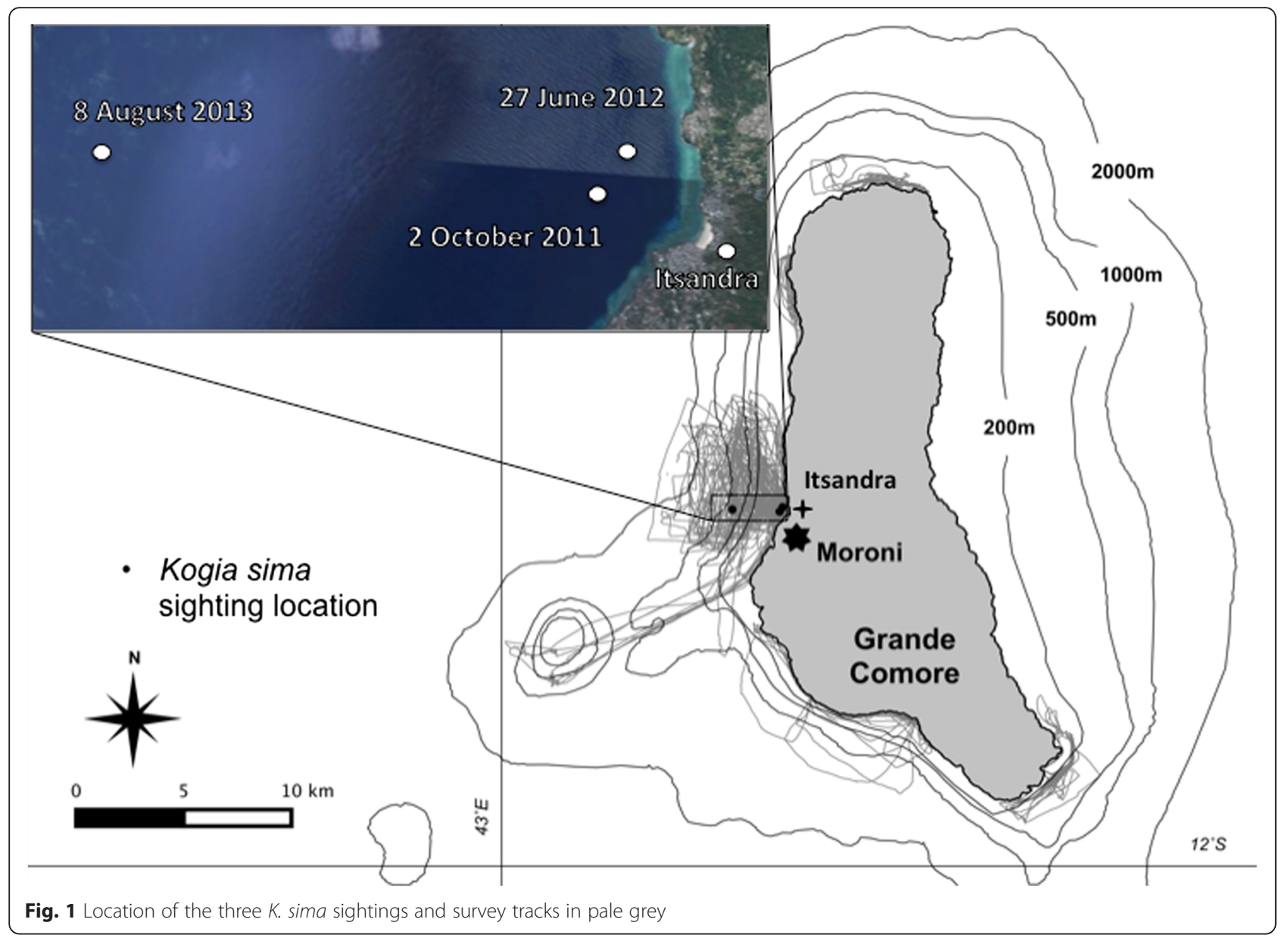

bathymetric map available at http://maps.ngdc.noaa.gov/ viewers/wcs-client/. Observations were made in good weather conditions $(\leq 3$ Beaufort scale, $\leq 3$ Douglas sea scale), and visibility of $\geq 2 \mathrm{~km}$ (following Evans and Hammond 2004). The majority (65\%) of surveys were made in Beaufort 0-1 conditions, $25 \%$ in Beaufort 2, and $10 \%$ in Beaufort 3 .

\section{Identification}

All the animals seen or photographed during the three sightings were quickly recognized as belonging to the genus based on the following characteristics: head ending abruptly with a vertical forehead, a flat back between the end of the head and dorsal fin, falcate dorsal fin with the trailing edge right at the surface of the water, and none of the tailstock visible (Fig. 2). During all three sightings, specific dwarf sperm whale characteristics were observed. The dwarf sperm whale is smaller than the pygmy sperm whale (Leatherwood et al. 1998), but its dorsal fin is larger and more erect (Caldwell \& Caldwell 1989; Duguy 1987; Jefferson et al. 2008). The dwarf sperm whale's dorsal fin is situated midway along the dorsal line, unlike the pygmy sperm whale's fin, which is closer to the tail (Baird 2005). When lying at the surface, because of these differences in body length and fin position, the dwarf sperm whale's back appears relatively flat anterior to the fin, as compared to the more rounded or slightly domed back of the pygmy sperm whale (Jefferson et al. 2008).

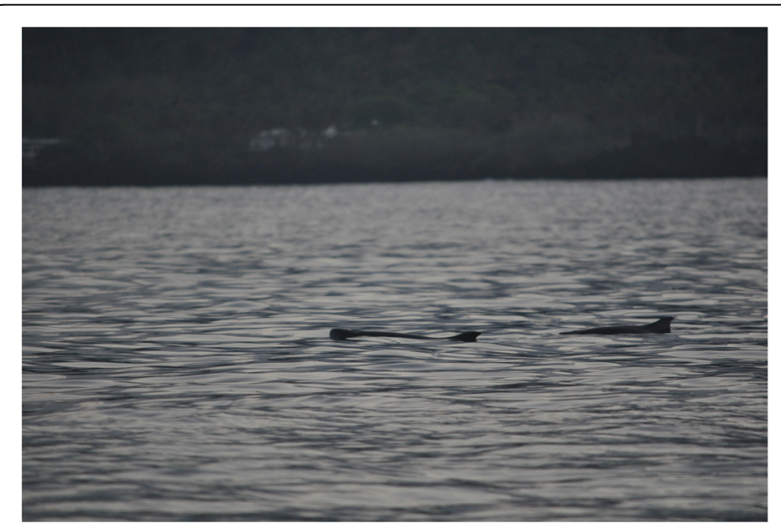

Fig. 2 Two K. sima on 2 October 2011, photo by M. Bonato 


\section{Results}

During the entire study, three sightings of dwarf sperm whales occurred, resulting in a mean sighting frequency (sightings per hour of effort) of 0.009 and a mean encounter rate (sightings per monitored $\mathrm{km}$ ) of 0.001 . For all three sightings, proximity to the animals enabled the observers to recognize $K$. sima's specific characteristics, and during the first and third sightings, photographs documented their morphology, confirming the species identity.

\section{First sighting}

On 2 October 2011 at 06:08, two dwarf sperm whales were observed $30 \mathrm{~m}$ from the boat in sunny conditions, moderate cloud coverage (30\%), calm seas (Beaufort $\leq$ 1 ), and light wind (Douglas $0-1$ ). The location was just outside the harbour of Itsandra Bay, approximately $600 \mathrm{~m}$ off the coast $\left(11^{\circ} 40.157^{\prime} \mathrm{S}, 43^{\circ} 14.852^{\prime} \mathrm{E}\right)$, at a depth of $32 \mathrm{~m}$ (Fig. 1). The sighting was of two animals, the larger estimated to exceed $2 \mathrm{~m}$ in length, and presumed to be an adult accompanied by a smaller animal, either a sub-adult or a small adult. When sighted, the two animals were floating and breathing noiselessly about $5 \mathrm{~m}$ away from each other. Approximately $2 \mathrm{~min}$ after the initial sighting, both animals made two short dives, disappearing from view and resurfacing, and then disappeared after the third dive. Both animals were photographed (Figs. 2 and 3).

\section{Second sighting}

The second sighting occurred on 27 June 2012 at 10:32. The location was $720 \mathrm{~m}$ off the coast $\left(11^{\circ} 40.157^{\prime} \mathrm{S}, 43^{\circ}\right.$ 14.852'E), in water $39 \mathrm{~m}$ deep (Fig. 1). Similar to the first sighting, the location was just outside of Itsandra Bay in sunny conditions, moderate cloud coverage (30\%), calm seas (Beaufort 1), and a light breeze (Douglas 1-2). The second sighting was also of two animals. We were underway when one animal surfaced $5 \mathrm{~m}$ in front of our boat; we stopped the boat immediately and the animal

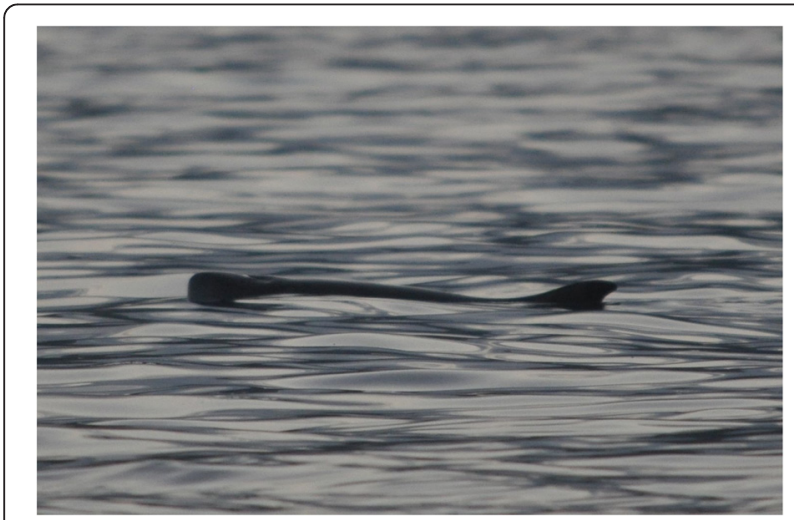

Fig. 3 Close up of one K. sima on 2 October 2011, photo by M. Bonato dived. Then two animals surfaced almost $20 \mathrm{~m}$ ahead, and were identified as Kogia. One dived immediately and disappeared, leaving no opportunity to identify it to species level, while the other remained on the surface, floating quietly, allowing time to identify it as a $K$. sima due to the characteristic profile and dorsal fin shape. It subsequently dived and was not resighted.

\section{Third sighting}

The third sighting occurred on 8 August 2013 at 06:22, $6 \mathrm{~km}$ off the coast of Itsandra Bay $\left(11^{\circ} 40.121^{\prime} \mathrm{S}, 43^{\circ}\right.$ $\left.12.739^{\prime} \mathrm{E}\right)$, in sunny conditions with low cloud coverage (10\%), calm seas (Beaufort 1) and a light breeze (Douglas 1-2). The water depth for the third sighting was $729 \mathrm{~m}$, much deeper than for the first two sightings (Fig. 1). Both animals were photographed, and observed to be clearly different in size. As with the first sighting, we presume the animals were an adult accompanied by a sub-adult, or a smaller adult. Upon sighting the two animals, we stopped the boat. The two animals dived immediately and surfaced nearly $35 \mathrm{~m}$ from the boat, then floated quietly about 3-5 m away from each other for $4 \mathrm{~min}$, and made two short dives. After a third dive they were not seen again (Fig. 4).

\section{Discussion}

The presence and distribution of the dwarf sperm whale in the Western Indian Ocean is poorly known. Our observations are interesting for several reasons. The sightings represent the first occurrences of dwarf sperm whales from the Union of the Comoros and establish new records for this area. Also, two of the three sightings came from Itsandra Bay and occurred in unusually shallow waters for this species, very close to shore and near a busy harbour entrance. Finally, the species was seen three times over three years in the same general area, in June, August, and October, suggesting a possible regular presence for the species in the waters around the

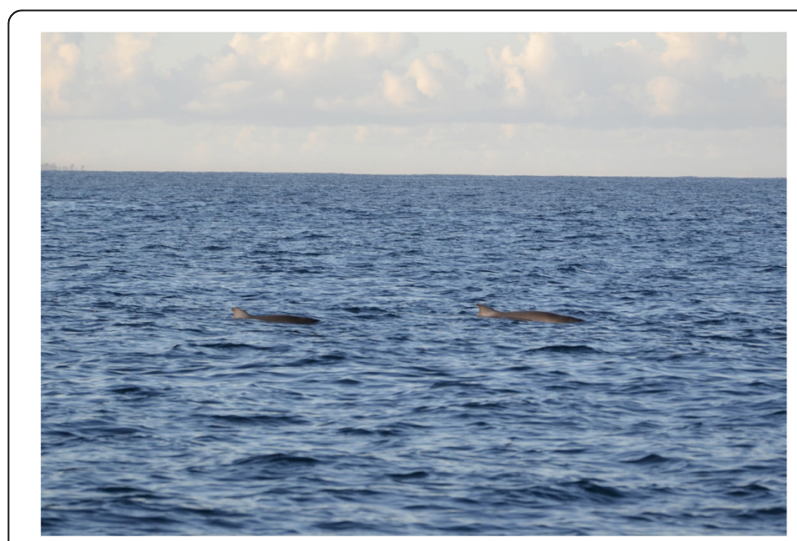

Fig. 4 Two K. sima on 8 August 2013 
Comoros. The third sighting came from deep waters outside of Itsandra Bay, but still relatively close to shore. Since our study area lies within the Agulhas Current Large Marine Ecosystem (Heileman et al. 2006), where upwelling and a productive ecosystem (Bakun et al. 1998; Lutjeharms 2006; Heileman et al. 2006) lead to a year-round consistent abundance and distribution of possible prey, we can reasonably suspect that the aggregation of prey on the continental slope (Dunphy-Daly \& Heithaus 2008) could attract K. sima. Dwarf sperm whales feed primarily on cephalopods and to a lesser extent on crustaceans and fishes, based on stomach contents of stranded animals (Ross 1979a; CardonaMaldonado \& Mignucci-Giannoni 1999). Although the diets of both species of Kogia may partially overlap (Plön et al. 1999), the relative contribution of prey types indicates that dwarf sperm whales have a preference for smaller squids and use shallower, warmer and more inshore waters than pygmy sperm whales (Ross 1979a; Candela 1987; Klages et al. 1989; Aurioles et al. 1993; Plön et al. 1999). Our observations also suggest that the Mozambique Channel, and particularly the Comoros Archipelago, with its narrow continental shelf and deep coastal waters, could be one of the few locations in the world close to shore, like the Bahamas, the Gulf of California, and the Kona coast off the Island of Hawaii, suitable for the study of dwarf sperm whales, one of the least known pelagic cetaceans. We found no records in the literature of apparently healthy dwarf sperm whales occurring in waters between $30-40 \mathrm{~m}$ deep, where two of our three sightings occurred. The only other instance where sightings of dwarf sperm whales occurred on the continental shelf in relatively shallow waters $(94 \mathrm{~m})$ was around the Bahamas (MacLeod et al. 2004). A very narrow, steep continental shelf bordering a deep abyssal trench may explain the occurrence of the dwarf sperm whales we observed, as well the record in the Bahamas. While it is appealing to think that the three occurrences of this species over different seasons are the result of a local year-round resident population near Itsandra Bay, more surveys are needed to confirm this conjecture. In any case, the presence of dwarf sperm whales should be taken into account as part of the cetacean fauna of the Union of the Comoros when developing marine conservation plans for the area.

\section{Abbreviations}

"Not Applicable".

\section{Acknowledgements}

Special thanks are due to Bill Keener for making useful suggestions that improved his manuscript, to Elena Papale for her critical revision of a previous draft and to Emilio Balletto for his encouragement and advice in improving the structure and effectiveness of our scientific writing. Thanks also go to two anonymous reviewers for their helpful comments. We are indebted to Dr. Ahmed Ouledi, coordinator of the EU B.I.R.D. project, who helped in many ways during this study and with Dr. Daniele Cagnazzi for his useful logistic aid in our research activity. The results presented here are based on the outcome of the B.I.R.D. project, contract FED/2009/217077 financed by ACP Science and Technology Programme, a program of the ACP Group of States, with the financial assistance of the European Union.

\section{Funding}

Data collection activity was performed in the framework of the projects B.I.R.D (Biodiversity Integration and Rural Development) (FED/2009/217077), ACP S\&T EU Programme and S.CO.R.E. (Supporting Cooperation for Research and Education) (9RPR-ACP-118\#36), ACP Edulink EU Programme.

\section{Availability of data and material}

"Not Applicable".

\section{Authors' contributions}

$M B$ and $A A$ carried out the field activity and the data collection. MB wrote the first draft of the manuscript, $A A, M W$ and $C G$ reviewed the manuscript and were involved in its critical revision before submission. All authors read and approved the final manuscript.

\section{Competing interests}

I confirm that I have read Biomed Central's Guidance on competing interest and all the Authors declare that they have no competing interest.

\section{Consent for publication}

"Not Applicable".

\section{Ethics approval and consent to participate}

"Not Applicable".

\section{Author details}

${ }^{1}$ Department of Life Science and System Biology, University of Torino, Via Accademia Albertina 13, Torino 10123, Italy. ${ }^{2}$ Department of Industrial Engineering (L.A.S.A.), University of Padova, Via Marzolo 9, Padova 35131, Italy. ${ }^{3}$ Golden Gate Cetacean Research, 9 Edgemar Way, Corte Madera, CA 94925, USA. ${ }^{4}$ Science and Technique, University of Comoros, Rue de la Corniche, Moroni, Union of the Comoros.

Received: 7 June 2016 Accepted: 8 June 2016

Published online: 27 July 2016

\section{References}

Aurioles GD, Urban RJ, Enriquez PL. Dwarf sperm whales stranding and sighting on the southwest coast of Gulf of California, Mexico. Galveston: Abstracts of the Tenth Biennial Conference on the Biology of Marine Mammals; 1993. p. 24.

Baird RW. Sightings of dwarf (Kogia sima) and pygmy (K. breviceps) sperm whales from the main Hawaiian Islands. Pacific Sci. 2005:59:461-6.

Bakun A, Claude R, Lluch-Cota S. Coastal upwelling and other processes regulating ecosystem productivity and fish production in the western Indian Ocean. In: Sherman K, Okemwa EN, Ntiba MJ, editors. Large marine ecosystems of the Indian Ocean: assessment, sustainability and management. Oxford: Blackwell Science; 1998. p. 103-41.

Balance LT, Pitman RL. Cetaceans of the western tropical Indian Ocean: distribution, relative abundance, and comparisons with cetacean communities of two other tropical ecosystems. J Cetacean Res Manag. 1998;3(2):213-8.

Bloch D, Mikkelsen B. A northernmost record of Dwarf Sperm Whale (Kogia sima) (Owen, 1866) from the Faroe Islands. Aquat Mamm. 2009;35(2):306-7.

Caldwell DK, Caldwell MC. Pygmy sperm whale Kogia breviceps (de Blaiinville 1838); dwarf sperm whales Kogia simus (Owen 1866). In: Ridgway SH, Harrison R, editors. Handbook of marine mammals, volume 4: river dolphins and the larger toothed whales. Waltham: Academic; 1989. p. 235-60.

Candela SM. Cephalopod prey of pygmy and dwarf sperm whales (Kogia breviceps and K. simus) stranded in Florida and Georgia. Miami: Abstracts of the Seventh Biennial Conference on the Biology of Marine Mammals; 1987. p. 9.

Cardona-Maldonado MA, Mignucci-Giannoni AA. Pygmy and dwarf sperm whales in Puerto Rico and the Virgin Islands, with a review of Kogia in the Caribbean. Caribb J Sci. 1999:35:29-37.

Duguy R. Rapport annuel sur le cétacés et pinnipèdes trouvés sur les côtes de France XVI - Année 1986 - Annales de la Société des Science Naturelles de la Charente. Maritime. 1987;7:617-39. 
Dunphy-Daly MM, Heithaus MR. Temporal variation in dwarf sperm whale (Kogia sima) habitat use and group size off Great Abaco Island, Bahamas. Mar Mamm Sci. 2008;24(1):171-82.

Evans PGH, Hammond PZ. Monitoring cetaceans in European waters. Mamm Rev. 2004;34:131-56.

Heileman S, Lutjeharms JRE, Scott LEP, Agulhas Current LME. Data from NOAA (National Oceanic Atmospheric Administration) on Large Marine Ecosystems. 2006. http://www.Ime.noaa.gov. Accessed 23 Jan 2011.

Jefferson TA, Webber M, Pitman RL. Marine mammals of the world: a comprehensive guide to their identification. 1st ed. Burlington: Academic; 2008.

Kiszka J, Erst P, Ridoux V. Cetacean diversity around the Mozambique Channel island of Mayotte (Comoros archipelago). J Cetacean Res Manag. 2007;9(2): 105-9.

Kiszka J, Muir C, Amir O, Drouot-Dulau V, Poonian C, Razafindrakoto Y, Wambiji N. Incidental catch of marine mammals in the southwest Indian Ocean: a preliminary review. Community Centred Conservation (C3) document. 2008. http://c-3.org.uk. Accessed 12 Mar 2012

Kiszka J, Erst P, Ridoux V. Structure of a toothed cetacean community around a tropical island (Mayotte, Mozambique Channel). Afr J Mar Sci. 2010;32(3):543-51.

Klages N, Cockcroft VG, Best PB. Stomach contents of pygmy (Kogia breviceps) and dwarf (Kogia simus) sperm whales stranded in South African beaches. Pacific Grove: Abstracts of the Eighth Biennial Conference on the Biology of Marine Mammals; 1989. p. 35.

Leatherwood S, Reeves RR, Perrin W, Evans WE. Whales, dolphins and porpoises of the North Pacific and adjacent Artic waters - a guide to their identification. New York: Dover Publications Inc: 1998 p. 198-200.

Lutjeharms JRE. The coastal oceans of South-eastern Africa. In: Robinson AR, Brink K, editors. The sea volume 14B, the global coastal ocean - interdisciplinary regional studies and syntheses. Cambridge: Harvard University Press; 2006. p. 781-832.

MacLeod C, Hauser N, Peckham H. Diversity, relative density and structure of the cetacean community in summer months east of Great Abaco, Bahamas. J Mar Biol Assoc UK. 2004;84:469-74.

Nagorsen DW, Stewart GE. A dwarf sperm whale (Kogia simus) from the Pacific coast of Canada. J Mamm. 1983;64:505-6.

Plön S. The status and natural history of pygmy (Kogia breviceps) and dwarf (K. sima) sperm whales off southern Africa, PhD thesis. Grahamstown: Rhodes University; 2004. p. 553

Plön SEE, Bernard RTF, Klages NTK, Cockcroft VG. Stomach content analysis of pygmy and dwarf sperm whales and its ecological implications: Is there niche partitioning? European Research on Cetacean-13. Valencia: Proceedings of the 13th Annual Conference of the European Cetacean Society; 1999. p. 336-9.

Rice DW. Marine mammals of the world: systematics and distribution. Society for Marine Mammalogy, Special Publication Number 4. Lawrence, KS. USA: Editor Wartzok D. 1998.

Ross GJB. Records of pygmy and dwarf sperm whales, genus Kogia, from southern Africa, with biological notes and some comparisons. Ann Cape Provincial Museums (Natural History). 1979a;15:259-327.

Ross GJB. The smaller cetaceans of the southern-east coast of Southern Africa, PhD thesis. Port Elizabeth: University of Port Elizabeth; 1979b. p. 415.

Wade PR, Gerrodette T. Estimates of cetacean abundance and distribution in the Eastern tropical Pacific. Rep Int Whaling Commission (Special Issue 6). 1993; 43:477-93.

Willis PM, Baird RW. Status of Dwarf Sperm Whale, Kogia simus, with special reference to Canada. Can Field Nat. 1998;112:115-25.

\section{Submit your next manuscript to BioMed Central and we will help you at every step:}

- We accept pre-submission inquiries

- Our selector tool helps you to find the most relevant journal

- We provide round the clock customer support

- Convenient online submission

- Thorough peer review

- Inclusion in PubMed and all major indexing services

- Maximum visibility for your research

Submit your manuscript at www.biomedcentral.com/submit

) Biomed Central 